\title{
PERENCANAAN STRATEGIK BERPARADIGMA ISLAM
}

\author{
S 1 a me t \\ Fakulti Teknologi dan Sains Maklumat \\ Universiti Kebangsaan Malaysia (UKM) Bangi Selangor \\ slamet_uinmlg@yahoo.co.id \\ HP. 081919764429
}

\begin{abstract}
Abstrak
The paper, which is part of the chapter of a recently completed dissertation in the field of strategic management of information system, deals with the strategic planning base on Islamic paradigm. Strategic planning base on Islamic paradigma is responses from the conventional strategic planning concept. The strategic planning base on Islamic paradigm is the planning concept in an organization which is comprehensively carried out along with the Islamic values and principles. The strategic planning base on Islamic paradigm has five main stages: (1) to develop a strategic planning initiative (why) whose purpose is to provide an answer to the question "why we initiate the planning"; (2) to determine the direction of the organizational goals (what), which is intended to answer the question of what is to be achieved by an organization in the future; (3) to assess and analyze the organizational environment (where), whose objective is to identify and understand the real position of the organization and simultaneously identify the factors that affect the achievement of organizational goals; (4) to chose as well as determine alternative strategies (how), which is designed to answer the question of how or what strategies can be used in achieving organizational goals; and (5) to develop a design implementation (when). The last point is to answer the question of when the program can be run based on the strategy set.
\end{abstract}

Keyword : Rencana Strategis, Paradigma Islam, Musyawarah

Dalam prakteknya, telah ada pelbagai konsep dan model perencanaan yang bisa digunakan oleh manajer khususnya dan tim perencanaan pada umumnya sebagai pendekatan dalam melakukan perencanaan dalam sebuah organisasi. Konsep dan model perencanaan yang baru adalah tanggapan terhadap konsep dan model perencanaan yang ada sebelumnya. Secara umum beberapa konsep dan model perencanaan yang diidentifikasi diantaranya adalah perencanaan induk, perencanaan komprehensif, perencanaan ekuiti, perencanaan dukungan (advocacy) (Djunaidi 2000), perencanaan jangka pendek (Hartomo 2002), perencanaan jangka panjang (Robson 1997; Bryson 2004; Allison \& Kaye 2005), dan perencanaan strategik (Djunaidi 2000; Bryson 2004; Allison \& Kaye 2005; Tripomo \& Udan 2004; Raja Malik 2003; Boar 2001). 
Setiap konsep dan model perencanaan tersebut mempunyai maksud dan tekanan yang berbeda-beda. Misalnya, perencanaan induk yang merupakan konsep dan model perencanaan tertua (Djunaidi 2000), biasanya digunakan oleh organisasi pemerintah dalam melakukan perencanaan dalam bidang pembangunan sebuah kawasan. Yang bertujuan untuk menyelaraskan penyusunan rancangan yang lebih terperinci (Dictionary of Business Terms 2007). Sementara perencanaan jangka pendek, perencanaan jangka panjang dan perencanaan strategik dapat digunakan oleh semua bentuk organisasi baik organisasi publik maupun swasta. Ia mempunyai maksud yang sama yaitu membuat perencanaan dengan mempertimbangkan keadaan internal dan eksternal organisasi. Perencanaan jangka panjang dan strategik biasanya digunakan untuk membuat perencanaan dalam jangka waktu yang panjang yaitu 5 hingga 25 tahun. Kedua konsep dan model perencanaan ini seringkali digunakan oleh sebagian pihak secara bergantian (Looker 1999; Harrison), tetapi sesungguhnya ia mempunyai tekanan yang berbeda (Robson 1997; Bryson 2004; Allison \& Kaye 2005). Perbedaan ini dapat diidentifikasi dari fokus tindakan, proses, penilaian lingkungan, ramalan, hasil keputusan, sifat dan pertanyaan sebelum melakukan perencanaan (Robson 1997; Boar 2001; Raja Malik 2003; Gasperzs 2004; Bryson 2004; Allison \& Kaye 2005).

Perencanaan strategik merupakan tanggapan dari konsep dan model perencanaan sebelumnya dan ia mulai berkembang pada dekad 20-an (Djunaidi 2000), tepatnya tahun 1950-an yang digunakan secara formal oleh organisasi korporat (Purnomo \& Zulkieflimansyah 2005). Ia dikenal sebagai pendekatan terbaik untuk mencapai keberhasilan organisasi di masa depan dalam lingkungan yang selalu berubah dan di luar kontrol (Rowley \& Sherman 2002; Zainal 1998). Penggunaan konsep dan model perencanaan strategik sebagai pendekatan perencanaan adalah bertujuan untuk menyiapkan suatu organisasi terhadap pelbagai ancaman dan peluang eksternal organisasi yang memerlukan tanggapan di masa depan (Bryson 2004), dengan keputusan yang dibuat saat ini (Azman 2003). Pelbagai alasan penggunaan terhadap perencanaan strategik sebagai pendekatan perencanaan organisasi di antaranya adalah perubahan lingkungan yang bersifat global, perubahan teknologi, persaingan, peningkatan modal intelektual dan meningkatnya tuntutan kualitas (Azman 2003; Pitts \& Lei 2006; Dess et al 2006; Haim 2005; David 2003). Keadaan seperti ini mensyaratkan manajer organisasi untuk berfikir futuristik dan bertindak secara strategik yang tidak pernah dilakukan sebelum-sebelumnya. Perencanaan strategik merupakan salah satu pendekatan yang dapat membantu menyelesaikan keadaan tersebut. 
Dalam konteks manajemen strategik, perencanaan strategik adalah langkah pertama dan paling utama (Rowley \& Sherman 2002; Tripomo \& Udan 2005; McNamara 2001). Oleh itu, perencanaan strategik mempunyai peranan yang penting dan kritis dalam menentukan apa yang dikehendaki oleh suatu organisasi. Merujuk kepada manajemen Islam, masalah utama dalam perencanaan adalah harus memikirkan nilai-nilai kemanusiaan, kesejahteraan dan kemaslahatan manusia yang berlandaskan syariah (Mustafa 2000; Abu Sinn 2006; Wan Liz Ozman 1996; Azman 2003). Dengan demikian, pencapaian yang hendak dicapai dalam perencanaan strategik sepatutnya tidak saja ditumpukan kepada aspek material, tetapi jauh lebih penting adalah pencapaian yang selaras dengan tujuan dalam manajemen Islam. Yang mana, manajemen Islam adalah berasaskan nilai-nilai (YAPEIM 2005), sehingga proses perencanaan strategik juga harus berasaskan nilai-nilai yaitu nilai-nilai yang terkandung dalam Islam yang relevan dalam proses perencanaan strategik.

Walaupun Islam tidak membicarakan secara khusus konsep perencanaan strategik, tetapi sesungguhnya ia bersumber dari Islam yang dikaji dan dikembangkan dalam teori manajemen yang dilahirkan Barat (Mohd. Sharifuddin 2004), yang kini digunakan dan diamalkan secara meluas tidak terlepas bagi umat Islam dalam memantapkan manajemen strategik sebuah organisasi. Kepentingan memahami masa depan dan seterusnya membuat perencanaan telah diperlihatkan oleh al-Quran. Misalnya surat al-Baqarah [2]:30; Yusuf [12]:47-49; ar-Ra'd [13]:2; Shaad [38]:27; dan adz-Dzaariyah [51]:56; al-Hasyr [59]:18. Ayatayat tersebut bukti bahwa Allah SWT adalah perancang yang teragung (Ismail 2000). Kisah Nabi Yusuf a.s dapat meramalkan masa depan ekonomi negara untuk jangka waktu empat belas tahun mendatang adalah bukti perencanaan strategik telah ada semenjak lahirnya Islam. Bukti lain adalah hijrah, dakwah dan masa peperangan yang dilakukan oleh Rasulullah s.a.w. Hijrah Baginda dan para sahabatnya adalah melakarkan konsep perencanaan strategik (al-Qardhawy 1996; al-Qardhawy 2003; Azman 2003). Baginda adalah seorang yang sudah terlibat dalam sistem perencanaan sejak awal Islam dan seorang yang proaktif, inovatif dan bervisi dalam merancang sesuatu proyek (Othman 2000). Baginda tidak pernah lupa dari mempersiapkan diri kepada umatnya untuk menghadapi masa depan dengan segala daya usaha yang selalu disertai jiwa bertawakal kepada Allah SWT (alQardhawy 2003).

Oleh karena Islam adalah agama yang berasaskan ilmu pengetahuan dan ilmu pengetahuan adalah asas semua keutamaan amal (Mohd. Wan Daud 2005), maka perlu ada pengulasan dan pemaknaan semula tentang konsep perencanaan strategik yang ada ada saat 
ini ke dalam konsep perencanaan strategik yang holistik dengan asas-asas Islam. Meskipun, secara definitif (takrifan) tidak jauh berbeda dengan takrifan yang difahami umum, tetapi Islam turut bermaksud memberikan keupayaan kepada individu atau organisasi agar mempunyai supaya mempunyai pedoman dalam melakukan proses perencanaan strategik berasaskan nilai-nilai dan prinsip-prinsip Islam. Islam menerima sesuatu ilmu pengetahuan yang tidak terdapat secara khusus dalam al-Quran, selagi ia tidak bercanggah dengan prinsip dan nilai syara' (Sharifah Hayati 2001). Islam mengakui dan menggunakan kebenaran ilmu pengetahuan yang diperkembangkan Barat (Wan Mohd. Nor 2003; Muliawan 2005; Muhaimin 2006; Al-Qardhawy 2003). Perkara ini juga diperjelas oleh Ibn Rushd yang menyatakan, sekiranya bangsa asing telah menguasai ilmu tersebut (falsafah), maka merupakan suatu kewajiban yang jelas kepada kita (orang Islam) supaya mempelajari dan mengambil faedah dari apa yang telah mereka kuasai. Tidak peduli bangsa tersebut beragama Islam atau tidak. Kita wajib membaca buku-buku mereka, meneliti dan menilai apa saja yang dijadikan teori. Sekiranya apa yang dikatakan itu betul, kita terima, dan sebaliknya jika salah kita tolak (Mohd. Nasir 2005

Merujuk Widjajakusuma \& Yusanto (2002), minimum ada empat kepentingan pengulasan dan pemaknaan semula tersebut, antaranya adalah (i) kepentingan akidah. Kepentingan akidah dimaksudkan agar supaya umat Islam sadar bawa akidah Islam adalah dasar ilmu pengetahuan dan aktivitas keilmuan; (ii) kepentingan kemanusiaan. Kepentingan kemanusiaan adalah konsekuensi logis dari kepentingan pertama, bahwa aktiviti keilmuan yang didasarkan dan dikontrol oleh iman akan mewujudkan manusia seutuhnya sesuai hakikat penciptaannya; (iii) kepentingan peradaban. Kepentingan ini dimaksudkan bahwa kehidupan dengan sistem dan segala aktivitasnya yang telah dikendalikan oleh iman yang dijalankan sesuai aturan Allah (syariah) secara konsisten akan membawa peradaban manusia; dan (iv) kepentingan ilmiah. Kepentingan terakhir adalah dimaksudkan bahwa semua aktivitas keilmuan selalu dapat dipertanggungjawabkan secara mendatar (kepada manusia lain) dan vertikal (yaitu wujudnya Allah SWT). Keempat kepentingan tersebut saling berhubungkait antara satu dengan lainnya.

\section{PERENCANAAN STRATEGIK BERPARADIGMA ISLAM}

Organisasi dan manajemen merupakan dua bagian yang tidak dapat dipisahpisahkan (Mohd. Shahar 1991; Hafidhuddin \& Tanjung 2003), ibarat uang logam yang mempunyai dua sisi. Organisasi didirikan dengan tujuan untuk mencapai taraf hidup 
manusia sebagai insan dan khalifah di muka bumi (Mohamed Yusof Nor et al. 1999), yang memerlukan sistem manajemen. Manajemen wujud karena wujudnya organisasi (Mohd. Shahar 1991; Azman 2003). Untuk menentukan tujuan organisasi dengan efektif, perencanaan strategik adalah pilihan terbaik (Rowley \& Sherman 2002; Zainal Abidin 1998). Oleh karena manusia bersikap dan bertindak selalunya dibina dan dibimbing oleh suatu bentuk ilmu pengetahuan, maka konsep asas Islam harus dimasukkan ke dalam tubuh ilmu pengetahuan apa pun yang dipelajari oleh umat Islam (al-Attas dalam Wan Mohd Nor 2003).

Islam adalah agama Allah SWT (QS al-Maa'idah [5]:3), yang diyakini sebagai ajaran yang sempurna, menyeluruh dan syumul (Muliawan 2005). Sehingga bagi umat Islam, Islam merupakan addin dan a way of life yang merangkumi setiap aspek bidang kehidupan. Islam sebagai agama mampu membimbing manusia memenuhi fitrah keperluan kejadiannya pada tingkat individu atau sosial. Ia mempunyai prinsip-prinsip dan nilai-nilai yang sangat dinamis dan relevan untuk menciptakan kualitas dan produktivitas masyarakat. Islam memandang kehidupan manusia dalam perspektif total yang sejajar dengan nilai-nilai kemanusiaan, yang meliputi individu, organisasi dan masyarakat. Islam juga merupakan proses yang membawakan perubahan positif dalam semua aspek usaha manusia dan tujuan akhirnya adalah memperbaiki kehidupan manusia (Nik Mustapha 2007; 2008). Manusia mempunyai kelebihan dibandingkan kebanyakan makhluk Allah SWT lainnya (QS al-Isra' [17]:70). Oleh itu, sebagai manusia beriman apabila hendak membuat atau melaksanakan urusan kehidupan perlu dilandasi oleh nilai-nilai dan prinsip-prinsip Islam.

Sementara paradigma bermakna teori, hukum, peraturan, model, konsep atau definisi yang secara umum diterima sebagai teori asas (Khun, Anon). Sedangkan, MedicalDictionary, mendefinisikan paradigma merupakan model umum yang menggambarkan fenomena tertentu. Di mana model atau pola merupakan nilai dalam melakukan sesuatu dalam sebuah organisasi atau masyarakat (Medical-dictionary Anon). Dengan demikian, dapat dinyatakan bahwa perencanaan strategik berparadigma Islam adalah sebuah konsep dan model dalam melakukan proses perencanaan strategik yang holistik dengan asas-asas Islam.

\section{ASAS-ASAS PERENCANAAN STRATEGIK}

Ajaran Islam adalah sangat luas, seluas hamparan bumi atau alam semesta. Oleh itu dalam menentukan asas-asas Islam yang terkait dengan perencanaan strategik dapat dikaji dari al-Quran, al-Hadits, sirah nabawiyah yang sangat terkait dengan konsep perencanaan 
strategik, termasuk konsep perencanaan strategik modern yang ada saat ini. Beberapa asasasas berikut yang sepatutnya dapat dijadikan landasan dalam melakukan proses perencanaan strategik :

\section{Berasaskan Tauhid}

Asas pertama dalam perencanaan strategik berparadigma Islam adalah tauhid, karena ketika membincangkan mengenai Islam sebagai satu cara hidup, tidak dapat memisahkan dengan asas Islam yaitu tauhid (Wan Liz Ozman 1996). Visi Islam itu sendiri adalah tauhid (Mohd. Shahar 1991). Tauhid adalah istilah Arab yang secara harfiah berarti "membuat jadi satu" atau "menyatukan" (Ensiklopedi Oxford 2001), atau "meng-esa-kan" (Rais 1999; Madjid 2000), yang bermakna penegasan tentang kemurnian keesaan Allah (QS al-Ikhlas [112]:1-4). Tauhid bermakna hanya Allah SWT sebagai Tuhan sekalian alam dan Maha Berkuasa ke atas sekalian makhluk-Nya (Wan Liz Ozman 1996).

Hasil dari perencanaan strategik berhasil atau tidak adalah semata-mata karena izin Allah SWT (QS al-Baqarah [2]:255). Untuk memperkukuh jiwa tauhid, manusia harus menyadari dan memahami hakikat hidup manusia (Al Qardhawy 1999). Oleh itu, apa pun yang diamalkan oleh manusia tidak boleh terlepas dari kebenaran dan percaya terhadap wujudnya Allah (Madjid et al. 1989), termasuklah aktivitas manajemen yang harus berlandaskan tauhid (Syedh Othman 1989; Yusof Ismail 1991; Wan Liz Ozman 1996; Othman 2000; Harussani 2005). Rasulullah s.a.w sendiri dalam mengamalkan manajemen melalui empat elemen utama, satu di antaranya adalah ajaran tauhid (Ismail 2000), dan budaya manajemen baginda juga budaya tauhid (Naceur 1994).

\section{Penyampaian Idea}

Allah SWT ketika hendak menciptakan manusia sebagai khalifah di muka bumi terlebih dahulu disampaikan kepada para malaikat (QS al-Baqarah [2]:30). Secara tersirat ia adalah cetusan idea. Rasulullah s.a.w sebagai seorang pimpinan umat manusia sejagat, ketika akan melakukan tindakan selalu dimulakan dengan prakarsa atau cetusan idea (AnNabhani 2006). Misalnya, Rasulullah s.a.w dalam menyebarkan agama yang rahmatan lil alamiin. Rasulullah s.a.w pertama-tama mengajak isterinya, Khadijah. Kemudian Rasulullah s.a.w mengajak putera pamannya, Ali. Rasulullah s.a.w mengajak budaknya, yaitu Zaid. Rasulullah mengajak sahabat karibnya, Abu Bakar. Seterusnya, Rasulullah s.a.w mulai menyeru masyarakat, maka sebagian beriman dan lainnya adalah kafir. Peristiwa hijrah 
pula, Rasulullah s.a.w bermula dengan cetusan idea untuk melakukan perubahan dalam strateginya.

Dalam konteks perencanaan strategik modern, penyampaian idea ada pada pihak pimpinan sebagai pemegang politic will (Hunger \& Wheelen 2001; Gaspersz 2004; Bryson 2004; Allison \& Kaye 2005). Ia mempunyai peranan besar dalam memulai proses perencanaan strategik. Walaupun keberhasilan tidak serta-merta karena pimpinan secara mutlak, tetapi ia perlu keterlibatan semua tingkat dalam organisasi untuk memperoleh dukungan, komitmen dan pengakuan semua stakeholder. Metode ini merupakan sumbangan besar dalam keberhasilan perencanaan strategik (Allison \& Kaye 2005).

\section{Mengedepankan Asas Musyawarah (syuura)}

Allah telah memberikan amaran kepada umat manusia untuk selalu melakukan musyawarah (syuura) dalam menyelesaikan segala perkara (QS Ali Imran [3]:159; AsySyuura [42]:38). Musyawarah adalah perundingan dengan pihak-pihak lain dalam menyelesaikan masalah atau mencapai persetujuan (Kamus Dewan 2005). Dengan musyawarah seseorang tidak menjadi egois dengan pendapatnya sendiri, karena pendapat dua orang atau pendapat kolektif lebih mendekati kebenaran dari pendapat seorang (alQardhawy 1999). Asas musyawarah dalam konteks perencanaan strategik berparadigma Islam adalah penyertaan atau penglibatan semua lini dalam proses membuat keputusan (Azman 2003).

Oleh itu, musyawarah adalah penting untuk dilakukan terutama semasa bekerja dalam sebuah tim (Danial 2006). Ia merupakan salah satu prinsip dalam sistem manajemen Islam (YPEIM 2005). Pendekatan terbaik untuk menghasilkan keputusan yang sesuai dengan nilai-nilai kemanusiaan dan sosial sesuai ajaran Islam adalah musyawarah (al-Qardhawy 1999). Di mana, Rasulullah s.a.w telah menjadikan musyawarah sebagai pendekatan dalam budaya kepimpinan dan sistem manajemen baginda (Naceur 1994; al-Munawar 2004). Rasulullah s.a.w senantiasa berunding dan bermusyawarah dengan para sahabatnya dalam banyak perkara, utamanya dalam urusan keduniaan dan pemerintahan. Ketika perang Badar, Rasulullah s.a.w telah mendapatkan pandangan dari al-Habbab ibn al-Munzir yang telah mencadangkan perubahan strategik dalam markas tentera. Ketika peperangan dengan Bani Ghattafan, Rasulullah s.a.w bersetuju dengan pandangan Saad ibn Muaz dan Saad ibn Ubadah untuk menggunakan taktik bertahan. Ketika Rasulullah sedang nazak, Rasulullah s.a.w telah menyerahkan kepada dua masyarakat Muslim untuk bersyura bagi memilih 
khalifah yang akan menerajui kerajaan setelah kewafatan Rasulullah s.a.w. Berasaskan syura, maka keputusan Sayidina Abu Bakar sebagai pengganti sah di kalangan pengikut Rasulullah s.a.w. Pada perang Uhud, Rasulullah s.a.w sendiri cenderung melakukan perang di dalam kawasan kota Madinah, tetapi atas pendapat dari jamaah Rasulullah memilih berperang di luar kawasan Madinah (Ismail 2000; al-Qardhawy 2003).

Dengan demikian, musyawarah adalah sebagai konsep dan sekaligus prinsip (Kurzman 2001). Musyawarah atau syuura sebagai konsep, pertimbangan kumpulan lebih mungkin melahirkan hasil yang adil dan logis untuk kebaikan bersama dari pilihan individu. Sedangkan, musyawarah sebagai prinsip, semua orang atau manusia memiliki hak dan kewajipan serta tanggungjawab yang sama.

\section{Menekankan Asas Pembagian Tugas}

Rasulullah s.a.w dalam melakukan pemerintahan tidak dilakukan sendiri (Danial 2006), tetapi didelegasikan kepada orang-orang yang tepat (Hafidhuddin \& Tanjung 2003). Rasulullah s.a.w sebagai seorang pimpinan manusia sejagat, dalam melakukan misinya, tidak dikerjakan secara sendiri. Yang mana pembagian tugas merupakan budaya dalam sistem manajemen berasaskan prinsip-prinsip Islam (Naceur 1994). Cara demikian ini telah menjadi salah satu syarat dalam perencanaan strategik (YPEIM 2005). Beberapa bukti Rasulullah s.a.w melaksanakan pembagian tugas sebagai pendekatan sekaligus dasar dalam sistem manajemen baginda antaranya adalah ketika baginda hendak mengantar surat-surat kepada para raja-raja di negara Arab yang berisi ajakan memeluk agama Islam. Surat ke Hiraklius dihantar oleh Dahyah bin Khalifah al-Kalabiy; surat ke Kisra melalui Abdullah bin Hadzafah as-Sahamiy; surat untuk an-Najasyi ditugaskan kepada Amru bin Umayyah alDhamiriy dan sebagainya (dinukilkan dari an-Nabhani 2006). Dalam melakukan strategistrategi hijrah dan perang pula, baginda membagikan para sahabat kepada beberapa kelompok (Danial 2006).

Dalam konteks perencanaan strategik modern, pembagian tugas dikenal dengan istilah pengorganisasian. Pada kerja tim, pengorganisasian pada hakikatnya mengandun makna sebagai proses penetapan struktur peranan, melalui penentuan aktivitas-aktivitas yang diperlukan untuk mencapai tujuan organisasi (Ahmad Ibrahim 2006). Kerja tim amat ditekankan karena ia adalah unsur penting yang menjamin kecemerlangan dan keberhasilan (Danial 2006). Karena kerja tim merupakan mentalitas dan sikap yang mengutamakan kepentingan organisasi (YPEIM 2005). 


\section{Menentukan Arah Tujuan Organisasi yang Hendak Dicapai}

Asas penting lain dalam perencanaan strategik, baik moden mahupun berparadigma Islam adalah menentukan arah tujuan organisasi yang akan dicapai. Kejelasan tujuan telah menjadi syarat penting dalam perencanaan strategik (YPEIM 2005). Satu diantara tuntutan dalam dunia modern adalah seseorang dilarang untuk menyerah dengan keadaan saat ini, ia harus secara terus-menerus memandang ke masa depan (Al-Qardhawy 2003).

Rasulullah s.a.w selalu berfikir dengan pendekatan futuristik dalam memikirkan masa depan Islam (Madjid 2000). Allah SWT menjadikan Nabi Muhammad s.a.w sebagai seorang rasul di muka bumi telah mempunyai matlamat. Visi Rasulullah s.a.w adalah mengajarkan ke-Esaan Allah (tauhid) kepada umat manusia. Misinya adalah rahmatan lil alamiin yaitu membawa rahmat bagi seluruh umat manusia. Sedangkan tujuannya adalah (i) mewujudkan kesejahteraan, kedamaian, ketenteraman umat manusia; (ii) mengajak kepada seluruh umat manusia meng-Esa-kan Allah SWT; (iii) meninggalkan tindakan yang bercanggah dengan Islam; (iv) menghilangkan ajaran ritual korban-hadiah seekor kambing atau unta kepada berhala; (v) kebiasaan minum-minuman keras (khamar) dan seumpamanya (dikutip dari Tahia al-Ismail 2002). Allah SWT menciptakan manusia juga mempunyai maksud dan tujuan yaitu sebagai khalifah (QS al-Baqarah [2]:30) dan sekaligus supaya beribadah kepada (QS adz-Dzaariyah [51]:56).

Dalam pandangan perencanaan strategik modern, menentukan arah tujuan diartikan sebagai usaha menentukan apa yang sepatutnya dicapai dan bagaimana mencapainya (Allison \& Kaye 2005), yang diwujudkan dalam bentuk visi, misi dan tujuan (Widjajakusuma \& Yusanto 2002). Tidak mungkin proses organisasi dapat berjalan dengan sempurna, ketika pernyataan visi, misi dan tujuan belum diwujudkan terlebih dahulu (Zainal Abidin 1998; 1999). Oleh itu, setiap organisasi menjadi satu keharusan mempunyai visi, misi, tujuan dan nilai yang dianuti.

\section{Memperhitungkan Asas Kemaslahatan (mashlahah) dalam Tujuan Organisasi.} Merujuk Rahardjo (1990), pada dasarnya seorang manajer tugas utamanya adalah mengambil keputusan dari waktu ke waktu. Sesuai ajaran Islam, pengambilan keputusan harus dilakukan dengan cara yang benar. Satu diantara kualitas seorang khalifah adalah mengambil keputusan di antara manusia dengan cara yang benar (QS Shaad [38]:26). Setiap 
keputusan harus mencapai keadilan dan kemaslahatan masyarakat (Wan Liz Ozman 1996). Allah SWT mensyariatkan hukumnya adalah untuk memelihara kemaslahatan manusia, sekaligus menghindari mafsadat (mudarat), baik di dunia mahupun di akhirat (Djamil 1997). Maksud syariat Islam adalah mewujudkan kemaslahatan manusia, yakni menarik manfaat, mengelakkan kemudaratan dan menghilangkan kesusahan (Yahya \& Rahman 1993). Perkara ini pula termaktub dalam al-Quran surat al-Anbiya [21]:107, yang maksudnya "dan tiadalah kami mengutus kamu, melainkan untuk (menjadi) rahmat bagi semesta alam".

Secara etimologi, kemaslahatan bermakna manfaat, keuntungan, kenikmatan, kegembiraan, atau segala daya usaha yang dapat mendatangkan perkara yang sama (Yazid 2004). Khallaf (1996) mengartikan kemaslahatan adalah mendatangkan keuntungan bagi umat manusia dan menolak mudarat serta menghilangkan kesulitan kepada mereka. Mengikut pemikir Muslim liberal, konsep kemaslahatan adalah melakukan kebaikan demi masyarakat dan mengelakkan perkara yang merugikan kepentingan masyarakat (Ensiklopedia Oxford 2001). Selaras dengan perkara ini, visi manusia sebagai khalifah adalah menjadi rahmat bagi seluruh alam (Hafidhuddin \& Tanjung 2003; Haim 2005). Dalam konteks manajemen Islam, matlamat organisasi harus memikirkan nilai-nilai kemanusiaan dan kesejahteraan serta kemaslahatan umat manusia yang merupakan falsafah sosial bagi sebuah organisasi, sehingga terwujud keberhasilan masyarakat yang sinergi antara dunia dan akhirat (al-falah) (Mohd. Affandi 1990; Ismail 2000; Azman 2003). Pencapaian al-falah merupakan matlamat hakiki dari penerapan nilai-nilai Islam pada semua segi kehidupan (Wan Liz Ozman 1996). Perencanaan yang baik pula ketika tercapainya al-falah (Naceur 1994).

\section{Melakukan Penilaian dan Analisis Lingkungan Organisasi}

Untuk mencapai visi, misi dan tujuan di masa depan, perlu didukung oleh strategi. Strategi yang baik ketika sesuai dengan lingkungan korporat (Igor Ansof dalam Yeoh 1993). Oleh itu, penilaian dan analisis lingkungan adalah penting untuk dilakukan bagi mendapatkan strategi yang sesuai dengan realitas dan logis. Pada zaman Rasulullah s.a.w belum wujud alat analisis lingkungan, tetapi Rasulullah s.a.w telah melakukan penilaian dan analisis lingkungan secara sistematik dan tindakan ini tidak bertentangan Islam (Zainal Abidin 1998). Ketika Rasulullah s.a.w memerintahkan para sahabat untuk berhïrah ke negeri Habsyah, dibandingkan berhijrah ke negeri Rum atau Parsi adalah karena penguasa di kedua negara berkenaan tidak menerima ajaran Rasulullah s.a.w. Pertimbangan logis dan 
empirik ini bukanlah dilakukan asal-asalan saja, tetapi dilakukan melalui penelitian, pengkajian dan perencanaan yang teliti dari segi peta politik, keagamaan dan masyarakat Habsyah pada masa itu (Tahia al-Ismail 2002). Segala keputusan Rasulullah s.a.w tidak didasarkan kepada asumsi-asumsi semata, tetapi dilakukan melalui satu proses analisis lingkungan (Al-Qardhawy 2003).

Dalam konteks perencanaan strategik modern, merumuskan strategik dan mencapai tujuan organisasi terlebih dahulu perlu mengenal pasti posisi organisasi (Azman 2003; Gaspersz 2004). Karena, perencanaan adalah tahap awal manajemen yang bermula dengan penetapan tujuan yang realistik dengan memperhitungkan kekuatan dan kelemahan (YPEIM 2005). Beberapa alat analisis lingkungan pada masa kini yang bisa digunakan dalam analisis lingkungan di antaranya adalah SWOT (strength, weakness, opportunity and treatment), EFAS (external factors analysis summary), SFAS (strategic factors analysis summary); Space (strategic, position and action evaluation) Matrix, BCG (boston consulting group) dan sebagainya.

\section{Menentukan Pemilihan dan Penetapan Strategi}

Strategi adalah cara terbaik untuk mencapai keberhasilan organisasi. Ia adalah ilmu siasah dan taktik perang atau siasah muslihat untuk mencapai sesuatu maksud atau rancangan yang teratur untuk mencapai keberhasilan (Kamus Dewan 2005), atau ilmu memanfaatkan segala sumber untuk mencapai tujuan organisasi (YPEIM 2005). Istilah strategi telah dikenal dan diamalkan oleh Rasulullah s.a.w dan para sahabat semasa melakukan hijrah dan semasa perang. Hijrah Rasulullah s.a.w adalah model manajemen strategik (YPEIM 2005). Dalam konteks perencanaan strategik modern, strategi merupakan langkah penting yang menunjukkan cara bagaimana mencapai misi dan tujuan yang telah ditetapkan (Hunger \& Wheelen 2001; Purnomo \& Zulkieflimansyah 2005).

Rasulullah s.a.w sesungguhnya adalah seorang pimpinan perang (jenderal) dan sebagai guru pertama tentang ilmu militernya. Ketika perang Mut'ah misalnya, Rasulullah s.a.w menyiapkan 3,000 orang lasykar dari pahlawan Islam terbaik yang dipimpin oleh Zaid bin Haritsah. Untuk memenangkan peperangan, strategi yang digunakan adalah menerapkan perang kilat (dinukilkan dari an-Nabhani 2006; Antonio 2007). Ketika melakukan hïrah, strategi yang diamalkan Rasulullah s.a.w, menugaskan Ali ibn Abu Talib r.a tidur di atas tempat tidur baginda. Perjalanan dari Mekah ke Madinah, Rasulullah s.a.w meminta bantuan seseorang yang berpengalaman dan arif. Rasulullah s.a.w memerintahkan seorang untuk menggembala kambing bagi mengelakkan bekas jalan yang dilalui oleh 
Rasulullah s.a.w. Ketika mendakwahkan ajaran Islam, strategi yang diamalkan Rasulullah s.a.w adalah memujuk orang-orang dekat baginda. Pertama sekali memujuk isterinya, Khadijah. Kemudian putera pamannya yaitu Ali, kemudian Maula yaitu Zaid, kemudian sahabat karibnya yaitu Abu Bakar. Seterusnya menyeru masyarakat secara luas (dikutip dari al-Qardhawy 2003; Antonio 2007). Perencanaan strategik ini menjadi titik tolak kepada hïrah dan penegakan negara Islam di Madinah (Danial 2006).

\section{Menekankan Keadilan ( $\left.a d l^{\prime}\right)$ dan Bertanggungjawab (Mas'uliyah)}

Merujuk Yusof Ismail (1991), keputusan strategi harus berlandaskan syariah. Dr. Abd. Al-Rahman Ibrahim al-Dhohayan (dalam Ideris 2004) menyatakan, tujuan manajemen Islam adalah tujuan syariat itu sendiri. Inti dari syariah adalah menjaga agama, jiwa, akal, keturunan dan harta (Djamil 1997; Ghazali 2001). Kelima-lima unsur berkenaan merupakan keperluan paling asas dan kritis bagi kehidupan manusia (Djamil 1997). Keputusan strategi yang baik adalah strategi yang dapat memberikan keadilan yang sewajarnya kepada semua pihak yang terlibat secara langsung dan tidak langsung dengannya (Haim 2005). Allah SWT memberikan peringatan kepada manusia untuk berlaku adil (QS an-Nisaa' [4]:58; alMaa'idah [5]:8; an-Nahl [16]:90). Keadilan ( $\left.a d l^{\prime}\right)$ merupakan salah satu prinsip kepimpinan dalam Islam yang diamalkan oleh Rasulullah s.a.w (Ismail 2000; Ahmad Ibrahim 2006), sekaligus prinsip asas dalam ajaran Islam (al-Qardhawy 1999; Nurhakim 2000).

Keadilan bermaksud meletakkan sesuatu perkara pada tempatnya (Azman 2003), memberikan kepada semua yang berhak akan haknya, sehingga tidak terjadi pengurangan hak dan tidak pula menyelewengkan atau menzalimi hak orang lain (Al-Qardhawy 1999). Mutadla al-Muthahhari (dalam Madjid 2000), keadilan mengandung pengertian perimbangan atau keadaan seimbang, keadilan mengandung makna persamaan dan tidak ada diskriminasi dalam bentuk apa pun; keadilan bermakna pemberian perhatian kepada hak-hak peribadi dan penunaian kepada siapa saja yang berhak; dan keadilan bermakna keadilan tuhan yang berwujud kemurahan-Nya.

Dalam konteks perencanaan strategik, menentukan atau merumuskan strategi merupakan pemikiran strategis dalam membuat pelbagai keputusan mengenai apa yang bisa dilakukan dan apa yang tidak boleh dilakukan (Allison \& Kaye 2005). Oleh itu sebagai khalifah segala keputusan harus dijalankan secara adil (QS Shaad [38]:26), dan bertanggungjawab terhadap sesuatu yang telah diputuskan (QS al-Maa'idah [5]:42). Karena, sebagai pimpinan dan manajer harus bertanggungjawab (mas'uliyah) kepada anggota 
organisasi (QS asy-Syu'araa [26]:215). Islam memerintahkan untuk berlaku adil terhadap diri sendiri, semua manusia, perkataan; pemberian kesaksian; dan Islam mengharamkan kezaliman terhadap diri sendiri mahupun orang lain (Al-Qardhawy 1999).

\section{Menyusun Rancangan Strategi sebagai Dasar Implementasi}

Dalam khazanah ilmu tasawuf, perencanaan bermakna melakukan niat. Niat perlu diteruskan dengan pelaksanaan (mujahadah) (Muhaimin 2006). Maka hasil perencanaan strategik yang telah dijalankan harus dicatat dalam bentuk dokumen. Perkara ini selaras dengan al-Quran surat al-Jatsiyah [45]:29, yang bermaksud "(Allah berfirman): "Inilah Kitab (catatan) kami yang menuturkan terhadap kamu dengan benar. Sesungguhnya kami Telah menyuruh mencatat apa yang telah kamu kerjakan". Dokumen hasil perencanaan strategik dapat dijadikan sebagai garis panduan pelaksanaan (mujahadah) dan pengawalan (muhasabah) sebuah proyek.

Dalam perencanaan strategik modern, membuat catatan bermakna membuat rancangan implementasi strategi yang telah diputuskan. Rancangan implementasi ini diwujudkan dalam bentuk gambaran atau pemetaan (roadmap). Pemetaan berisi informasi tentang apa dan bagaimana strategi diimplementasikan (Hunger \& Wheelen 2001; Raja Malik 2003; Bryson 2004), yang diwujudkan dalam bentuk program-program dan prosedurprosedur (Hunger \& Wheelen 2001). Pada tahap ini terdapat aktivitas pembagian sumber daya organisasi, seperti sumber daya manusia, sumber daya keuangan, sumber daya material dan rancangan tindakan lainnya (Hunger \& Wheelen 200; Haim 2005). Oleh sebab itu, dalam menyusun rancangan strategik sebagai dasar implementasi sebuah proyek harus dilandasi oleh beberapa prinsip, antaranya prinsip keadilan $(a d l)$, prinsip musyawarah (syuura), prinsip keseimbangan (tawazun), prinsip prioriti (awlawiyat), prinsip bertahap (tadaruuj).

\section{Mengembangkan Prinsip Keseimbangan (tawazun).}

Prinsip keseimbangan merupakan pendekatan penting untuk dilakukan, karena dalam konteks manajemen Islam tidak hanya keuntungan dalam bentuk material yang hendak dicapai, tetapi kesejahteraan dan kebahagiaan manusia sebagai anggota organisasi pula patut dipertimbangkan. Allah sendiri menciptakan alam dan isinya mempertimbangkan keseimbangan. Misalnya keseimbangan antara hamparan bumi dan langit sebagai atapnya (QS al-Baqarah [2]:22); menciptakan sesuatu secara berpasang-pasangan (QS ar-Ra'd [13]:3); 
Allah menciptakan sesuatu sesuai kadarnya (QS al-Hijr [15]:19); Allah menciptakan seorang lelaki dan perempuan ... (QS al-Hujurat [49]:13). Model manajemen Rasulullah s.a.w adalah tercapainya al-falah yaitu keseimbangan antara kebahagiaan dunia dan akhirat (Wan Liz Ozman 1996; Zainal Abidin 1999; Ismail 2000; Azman 2003). Sabda Rasulullah s.a.w “belanja paling utama seorang lelaki adalah satu dinar untuk keluarga dan satu dinar diberikan kepada hewan yang ditumpangi ketika menuju jalan Allah (HR Bukhari Muslim).

\section{Mengembangkan Prinsip Skala Prioritas (awlawiyat)}

Oleh karena keupayaan organisasi terhadap sumber daya organisasi adalah sangat terbatas, maka rancangan tindakan perlu dilakukan dengan mempertimbangkan skala prioritas. Beberapa ayat Allah yang mensyaratkan yang selaras dengan masalah ini diantaranya adalah QS Muhammad [47]:10 yang bermaksud “... mohonlah ampunan bagi dosa kamu dan bagi orang-orang mukmin ....", QS al-Baqarah [2]:219 yang bermaksud “... yang lebih dari keperluan”, QS an-Nur [24]:35 yang bermaksud “... cahaya di atas cahaya (berlapis-lapis) ..". Rasulullah s.a.w juga mensyaratkan kepada umatnya berdasarkan skala prioritas dalam tindakannya. "Siapa orang yang paling kamu hormati, jawabnya adalah ibu, ibu lalu bapak kamu (HR Bukhari Muslim). "Amalan paling utama adalah beriman kepada Allah, lalu, berjuang di jalan Allah, lalu, haji mabrur" (HR Bukhari Muslim).

\section{Mengembangkan Prinsip Bertahap (tadaruuj).}

Pasangan dari pendekatan skala prioritas adalah pendekatan bertahap. Ia bermakna bahwa rancangan strategik yang dinyatakan dalam bentuk roadmap perlu memperhitungkan pelaksanaannya (mujahadah) yaitu prinsip bertahap (tadarruj). Prinsip ini memungkinkan program strategi dapat dilakukan secara rapi dan memudahkan untuk melakukan pengawasan (muhasabah). Rasulullah s.a.w dalam melakukan dakwah menyebarluaskan ajaran Islam dijalankan secara bertahap (an-Nabhani 2006; Antonio 2007). Allah SWT juga menyerukan kepada manusia dalam melakukan sesuatu perlu secara bertahap (QS an-Nisaa' [4]:43; al Maa'idah [5]:90-91). Allah SWT dalam menurunkan al-Quran dengan cara bertahap (Djamil 1997).

\section{Menekankan Prinsip Amanah}

Tanggungjawab (mas'uliyah) dalam melakukan proses perencanaan strategi adalah amanah Allah SWT. Sebagai manusia bertauhid apa pun yang dikerjakan adalah amanah 
(Mohd. Shahar 1991), dan hidup ini juga amanah (Danial 2006). Penyerahan tugas kepada seseorang yang berasaskan keahliannya adalah sebagai suatu amanah (YPEIM 2005). Oleh itu, setiap insan dalam melakukan tugas harus mempunyai kesadaran wujudnya Allah SWT. Dengan mengingat setiap apa yang dilakukan mempunyai reward di dunia dan di akhirat (Harussani 2005). Allah SWT menyerukan kepada umat-Nya selalu beramanah (QS anNisaa' [4]:58; al-Anfaal [8]:27; al-Ahzab [33]:72). Sabda Rasulullah s.a.w “jika engkau siasiakan amanah, maka tunggulah kehancuran" (HR Bukhari Muslim). Amanah adalah satu diantara prinsip manajemen Rasulullah s.a.w (Ismail 2000). Ia merupakan akar dalam mencapai kecemerlangan (Danial 2006).

\section{Mengembangkan Prinsip Sikap Bertawakal}

Selepas membuat perencanaan sebagai usaha yang telah dilakukan adalah bersikap bertawakal kepada Allah SWT (Danial 2006; YPEIM 2005). Seperti mana manusia bertauhid, setelah usaha terbaik dilakukan dan mengakui kekurangan dalam melaksanakan semua aktivitasnya, manusia diwajibkan untuk bertawakal. Ia bermakna berserah diri kepada Allah SWT setelah berikhtiar, percaya dengan sepenuh hati kepada Allah SWT selepas dijalankan ikhtiar (Kamus Dewan 2005). Sikap bersandar dan mempercayakan diri kepada Allah SWT (Madjid 2000). Allah SWT mengisyaratkan kepada umat manusia untuk selalu bertawakal (QS al-Maa'idah [5]:58; Yunus [10]:84; al-Hasyr [59]:18; Ali-Imran [3]:159; al-Kahfi [18]:23). Rasulullah s.a.w adalah orang yang paling bertawakal kepada Allah SWT (al-Qardhawy 2003), walaupun baginda telah membuat persiapan dan menyediakan perencanaan.

Berdasarkan uraian di atas, dapat diringkaskan sebagaimana tabel berikut.

\section{Asas-Asas Strategik Berparadigma Islam}

\begin{tabular}{cc}
\hline No & \multicolumn{1}{c}{ Asas } \\
\hline AIPS.1 & Berpaksikan tauhid \\
AIPS.2 & $\begin{array}{l}\text { Berniat, yang dinyatakan } \\
\text { dalam bentuk cetus } \\
\text { idea/prakarsa }\end{array}$ \\
\end{tabular}

AIPS.3 Keputusan penting harus diputuskan berasaskan

QS 2:21,22,255; QS 112:1-4; Syedh Othman (1989); Madjid et al. (1989); Mohd. Shahar (1991); Yusof (1991); Naceur (1994); Wan Liz Ozman (1996); alQardhawy (1999); Rais (1999); Ridzuan \& Sanep (2000); Othman (2000); Ismail (2000); Madjid (2000); Ensiklopedia Oxford (2001); YPEIM (2005); Harussani (2005)

QS 2:30; Hunger \& Wheelen (2001); Gaspersz (2004); Bryson (2004); Allison \& Kaye (2005); AnNabhani (2006)

QS 3:159; QS 42:38; Naceur (1994); al-Qardhawy (1999); Ismail (2000); Kurzman (2001); al- 
musyawarah (syuura)

AIPS.4 Perencanaan strategik harus dilakukan secara tim.

AIPS.5 Menentukan arah tujuan organisasi yang hendak dicapai, yang dinyatakan dalam bentuk pernyataan visi, misi \& tujuan.

AIPS.6 Memperhitungkan kemaslahatan (mashlahah) manusia dalam tujuan organisasi

AIPS.7 Terlebih dahulu dilakukan penilaian dan analisis lingkungan bagi mengindentifikasi dan memahami pelbagai keadaan organisasi saat ini

AIPS.8 Menentukan dan merumuskan pelbagai alternatif strategi untuk mencapai visi, misi \& tujuan

AIPS.9 Harus dilandasi oleh prinsip jiwa adil ( $a d l$ ), dan
Qardhawy (2003); Azman (2003); al-Munawar (2004); Kamus Dewan (2005); YPEIM (2005); Ahmad Ibrahim (2006); Danial (2006)

Naceur (1994); Hafidhuddin \& Tanjung (2003); YPEIM (2005); Danial (2006); an-Nabhani (2006); Ahmad Ibrahim (2006)

QS 2:30; QS 51:56; Zainal Abidin (1998), (1999); Madjid (2000); Widjajakusuma \& Yusanto (2002); Tahia al-Ismail (2002). Al-Qardhawy (2003); Hafidhuddin \& Tanjung (2003); Allison \& Kaye (2005); Haim (2005); YPEIM (2005)

QS 21:107; QS 38:26; Mohd. Affandi (1990); Rahardjo (1990); Yazid (2004); Naceur (1994); Wan Liz Ozman (1996); Khalaf (1996); Ismail (2000); Ensiklopedia Oxford (2001); Azman (2003); Hafidhuddin \& Tanjung (2003); Haim (2005)

Yeoh (1993); Zainal Abidin (1998); Ismail (2000); Tahia al-Ismail (2002); al-Qardhawy (2003); Azman (2003); Bryson (2004); Gaspersz (2004); Allison \& Kaye (2005); YPEIM (2005)

Hunger \& Wheelen (2001); Al-Qardhawy (2003); Kamus Dewan (2005); Purnomo \& Zulkieflimansyah (2005), Allison \& Kaye (2005); YPEIM (2005); an-Nabhani (2006); Danial (2006); Antonio (2007)

QS 4:58; QS 5:8; QS 16:90; QS 38:26; Yusof Ismail (1991); Djamil (1997); al-Qardhawy (1999); Ismail (2000); Nurhakim (2000); Madjid (2000); Ghazali (2001); Azman (2003); Ideris (2004); Haim (2005); Allison \& Kaye (2005); Ahmad Ibrahim (2006); Danial (2006)

bertanggungjawab (mas'uliyah) QS 5:42; QS 26:215

terhadap apa yang

diamanahkan

AIPS.10 Menyusun rancangan implementasi strategi dalam bentuk dokumen sebagai bukti
dalam melaksanakan amanah

AIPS.11 Mengambil kira prinsip

QS 2:22; QS 13:3; QS 15:19; QS 49:13; Wan Liz keseimbangan (tawazun) dalam Ozman (1996); Zainal Abidin (1999); Ismail (2000); setiap keputusan strategi dan Azman (2003)

membahagi sumber daya organisasi

AIPS.12 Memperhitungkan prinsip skala prioritas (awlawiyat) terhadap program-program yang lebih penting
QS 45:29; Hunger \& Wheelen 2001; Raja Malik 2003a; Bryson 2004; Haim 2005; Indrajit \& Djokopranoto 2006; Muhaimin (2006)

QS 2:22; QS
Ozman (1996)
Azman (2003)

QS 2:219; QS 24;35; QS 47:19; HR Bukhari Muslim 
AIPS.13 Memperhitungkan prinsip bertahap (tadaruuj) dalam pelaksanaannya

AIPS.14 Melakukan proses perencanaan strategik perlu dilandasi oleh prinsip amanah

AIPS.15 Berpegang teguh prinsip bertawakal ketika selesai melakukan pekerjaan
QS 4:43; QS 5:90,91; Djamil (1997); An-Nabhani (2006); Antonio (2007)

QS 4:58; QS 8:27; QS 33:72; HR Bukhari Muslim; Mohd. Shahar (1991); Ismail (2000); YPEIM (2005); Harussani (2005); Danial (2006)

QS 3:159; QS 5:58; QS 10:84; QS 18:23; QS 59:18; Madjid (2000); Al-Qardhawy (2003); YPEIM (2005); Kamus Dewan (2005); Danial (2006)

\section{TAHAPAN PERENCANAAN STRATEGIK BERPARADIGMA ISLAM}

Tahapan dalam perencanaan strategik berparadigma Islam merupakan syarat yang harus dijalankan ketika melakukan proses perencanaan strategik. Di mana, syarat adalah tindakan yang diperlukan untuk mencapai sesuatu yang dimaksudkan atau ketentuan (rukun, peraturan dan lainnya) yang harus dipatuhi (Kamus Dewan 2005). Gambar berikut adalah tahapan perencanaan strategik berparadigma Islam. Terdapat lima tahapan utama dalam perencanaan strategik berparadigma Islam dan setiap tahapan dilandasi oleh prinsip dan nilai Islam yang holistik ketika melakukan proses perencanaan strategik. Komponenkomponen setiap tahapan dapat diperkembangkan mengikuti maksud dan fokus konteks yang hendak dijadikan perencanaan. 


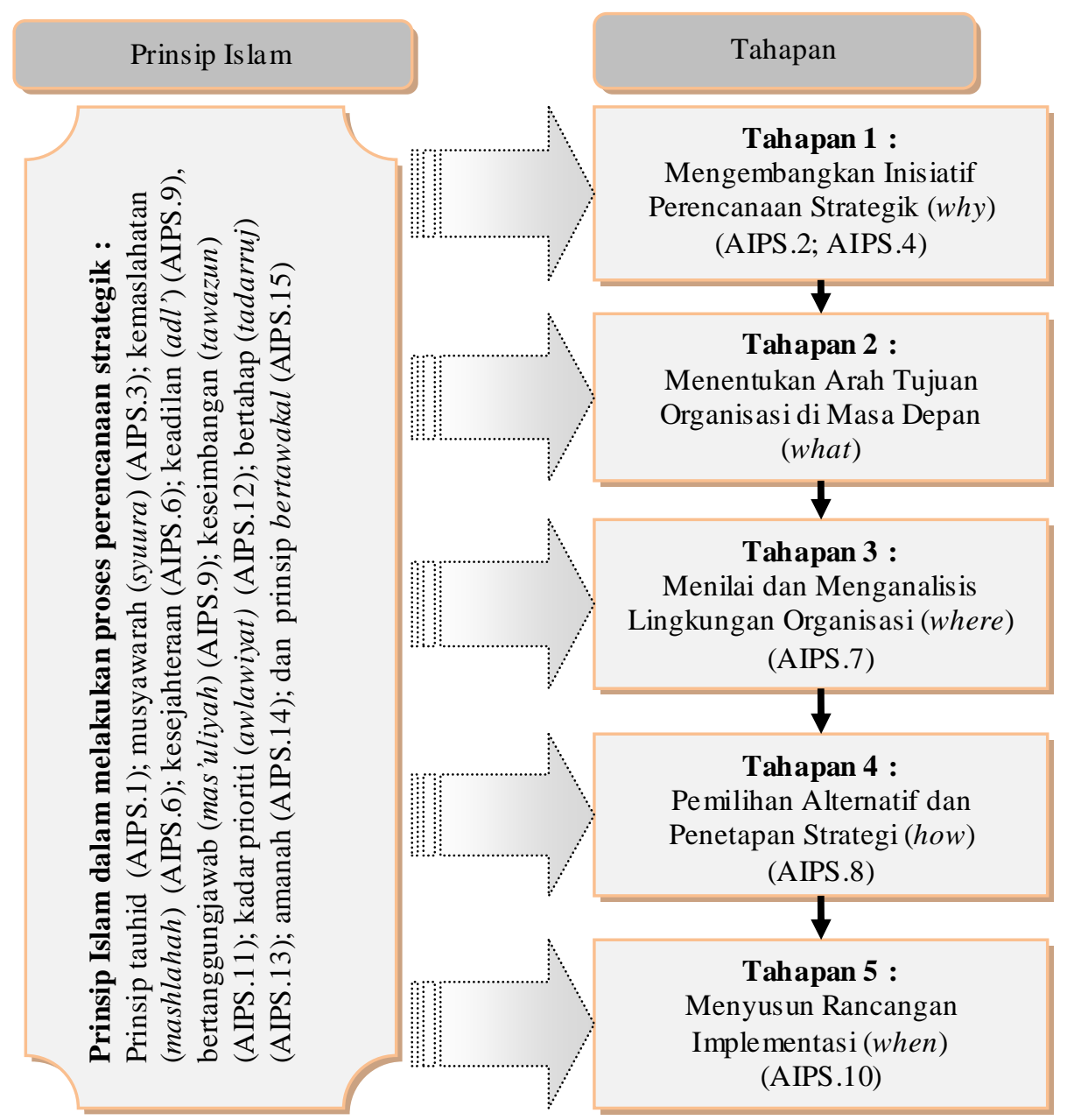

Tahapan Perencanaan Strategik Berparadigma Islam

\section{Tahapan 1 : Mengembangkan Inisiatif Perencanaan Strategik (why)}

Tahapan ini merupakan tahapan penting dalam mencapai keberhasilan baik semasa proses perencanaan strategik maupun implementasi hasil perencanaan strategik. Untuk mencapai masalah tersebut, satu tindakan penting adalah mengembangkan pemahaman dan komitmen semua stakeholder sebuah organisasi. Langkah ini memberikan sumbangan besar dan sekaligus menghindari rintangan dan kegagalan yaitu dengan cara melibatkan semua stakeholder internal organisasi. Tahapan pertama ini mempunyai makna yang besar terhadap nilai-nilai stakeholder, sebab mereka merasa diakui akan haknya dan merasa dilibatkan terhadap keputusan-keputusan organisasi. Tahapan pertama ini juga adalah menjawab pertanyaan mengapa (why) harus melakukan perencanaan strategik yang dijalankan oleh organisasi. Sehingga masalah-masalah yang perlu dibincangkan adalah ancaman, peluang dan tantangan yang dihadapi oleh organisasi; mengapa harus melakukan perencanaan 
strategik; apa dampak ketika tidak atau melakukan perencanaan strategik; apa yang sedang dan akan terjadi pada eksternal organisasi; dan sebagainya. Selepas mengembangkan inisiatif perencanaan strategik dan adanya pemahaman dan komitmen perlu dilanjutkan pembentukan panitia proses perencanaan strategik baik yang bersifat ad hoc atau berkelanjutan. Hal ini selaras dengan AIPS.2 dan AIPS.4.

Hasil yang diharapkan dari tahapan pertama adalah membangun satu pemahaman dan komitmen stakeholder terhadap proses perencanaan strategik dan implementasinya. Selain itu juga diharapkan wujud kesadaran dari stakeholder akan terjadinya perubahan internal organisasi, seperti perubahan sistem, prosedur, sumber daya manusia, budaya dan struktur organisasi.

Pada tahapan pertama ini, beberapa prinsip Islam yang harus dibangunkan oleh tim perencanaan strategik adalah asas tauhid (AIPS.1), asas musyawarah (syuura) (AIPS.3), asas amanah (AIPS.14), asas bertanggungjawab (mas'uliyah) (AIPS.9) dan asas kemaslahatan (mashlahah) (AIPS.6). Sedangkan, nilai-nilai yang patut dikembangkan oleh tim perencanaan strategik pada tahapan pertama ini adalah wujud keyakinan yang berasaskan tauhid; proses pengambilan keputusan harus diputuskan secara kolektif $\left(j a m a^{\prime} y\right)$; mempunyai pemahaman yang sama; tugas adalah amanah; terbuka menerima perubahan; kebebasan menyatakan fikiran dan kesediaan mendengarkan pendapat; dan apa yang dilakukan adalah sematamata demi kemaslahatan (mashlahah) bersama.

\section{Tahapan 2 : Menentukan Arah Tujuan Organisasi di Masa Depan (what)}

Menentukan arah tujuan organisasi adalah menentukan gambaran konseptual tentang arah dan tujuan yang hendak dicapai. Arah tujuan ini diwujudkan dalam bentuk pernyataan visi, misi dan tujuan. Bagi organisasi yang betul-betul baru perlu merumuskan pernyataan visi, misi dan tujuan yang baru. Sedangkan bagi organisasi yang sudah pernah mempunyai visi, misi dan tujuan, maka perlu menegaskan kembali visi, misi dan tujuan yang telah ada. Visi merupakan gambaran arah tujuan yang akan dicapai oleh sebuah organisasi. Misi merupakan pernyataan singkat apa yang harus dilakukan oleh organisasi. Misi membedakan antara organisasi yang satu dengan organisasi yang lain. Sedangkan, objektif adalah rumusan apa yang harus diselesaikan dan kapan diselesaikan dalam waktu tertentu. Perumusan visi, misi dan tujuan harus disesuaikan dengan perkembangan lingkungan organisasi dan sekaligus memberikan kemaslahatan (mashlahah) kepada stakeholder organisasi. Penetapan visi, misi dan tujuan harus melibatkan stakeholder kunci 
organisasi bagi memperoleh dukungan dan komitmen dari stakeholder organisasi. Sehingga pernyataan visi, misi dan tujuan tidak hanya sebagai hiasan, tetapi jauh lebih penting adalah sebagai garis panduan (guide line) arah operasi organisasi di masa depan.

Tahapan merumuskan arah tujuan organisasi yang diwujudkan dalam bentuk pernyataan visi, misi dan tujuan ini tidak bertentangan dengan konsep manajemen Islam, justeru diperintahkan. Sebab organisasi harus mempunyai visi, misi dan tujuan. Kegagalan dapat terjadi karena tanpa arah dan maksud organisasi yang jelas. Tahapan kedua ini berasaskan kepada asas perencanaan strategik kelima (AIPS.5). Dan hasil yang diharapkan dari tahapan kedua ini adalah satu set pernyataan visi, misi dan tujuan yang telah diputuskan bersama stakeholder.

Bagi memastikan pernyataan visi, misi dan tujuan mempunyai nilai dan harapan bagi semua stakeholder, maka tim perencanaan strategik perlu memperhatikan prinsipprinsip Islam sebagai landasan dalam melakukan proses perencanaan strategik. Prinsip tersebut diantaranya adalah asas tauhid (AIPS.1), asas musyawarah (syuura) (AIPS.3) dan asas kemaslahatan (mashlahah) (AIPS.6). Sedangkan, nilai-nilai yang patut dikembangkan adalah komitmen yang utuh pada Tuhannya (tauhid); keberhasilan hanya karena izin Allah; hidup harus mempunyai arah dan panduan jauh ke masa depan; harkat dan martabat manusia adalah sama di hadapan Allah, kecuali takwa; kebebasan menyatakan fikiran dan kesediaan mendengarkan pendapat; keputusan harus diputuskan secara kolektif (jama'y); manusia sebagai khalifah visinya adalah menjadi rahmat bagi seluruh alam; dan apa yang dilakukan adalah semata-mata demi kemaslahatan (mashlahah) bersama.

Tahapan 3 : Melakukan Penilaian dan Menganalisis Lingkungan Organisasi (where).

Untuk mencapai visi, misi dan tujuan yang telah ditetapkan pada tahapan sebelumnya, diperlukan pelbagai alternatif strategi. Strategi yang baik ketika sesuai dengan keadaan lingkungan organisasi yang sebenarnya. Untuk itu, mengindentifikasi, mengamati, menilai dan menganalisis lingkungan secara teliti dan terperinci adalah satu masalah penting untuk mencapai keberhasilan pencapaian visi, misi dan tujuan yang telah ditetapkan oleh organisasi. Keadaan lingkungan organisasi dapat dinilai dari internal dan eksternal organisasi. Analisis lingkungan bertujuan untuk menentukan gambaran keadaan lingkungan yang berpengaruh terhadap organisasi. Gambaran keadaan lingkungan ini dapat dijadikan sebagai landasan penentuan dan keputusan strategi. Karena salah satu kegagalan strategi adalah lemahnya atau kurang berhati-hatinya dalam analisis lingkungan. Dengan 
analisis lingkungan ini dapat ditentukan keadaan mana yang menjadi kekuatan, kelemahan, peluang dan ancaman yang dihadapi oleh organisasi. Tahapan ketiga ini adalah selaras dengan asas perencanaan strategik ketujuh (AIPS.7) yaitu melakukan asas penilaian dan analisis lingkungan organisasi

Hasil yang diharapkan dari tahapan ketiga perencanaan strategik berparadigma Islam adalah informasi tentang faktor-faktor yang mempengaruhi organisasi; informasi tentang sejumlah masalah penting yang menuntut tanggapan organisasi; informasi tentang keadaan organisasi yang digambarkan dalam bentuk kekuatan, kelemahan, peluang dan ancaman yang dihadapi oleh organisasi. Untuk mencapai hasil yang diharapkan secara maksimal dan memberikan arti kepada organisasi, tim perencanaan perlu mengembangkan beberapa prinsip Islam sebagai landasan dalam melakukan proses perencanaan strategik, di antaranya adalah asas tauhid (AIPS.1), asas musyawarah (syuura) (AIPS.3), asas keadilan (adl) (AIPS.9.), asas amanah (AIPS.14), asas keseimbangan (tawazun) (AIPS.11) dan asas bertahap (tadarruj) (AIPS.13). Sedangkan, nilai-nilai yang perlu dikembangkan semasa melakukan proses perencanaan strategik adalah bertunjangkan tauhid; bersikap progresif dalam melakukan penilaian lingkungan; bersikap dengan memperhitungkan pelbagai masalah yang sesuai pada tempatnya; pengambilan keputusan harus diputuskan secara kolektif (jama'y); mengembangkan rasa bertanggungjawab (mas'uliyah); dan penilaian lingkungan perlu dijalankan secara bertahap (tadarruj).

Tahapan 4 : Pemilihan Alternatif dan Penetapan Strategi (how)

Hasil analisis lingkungan adalah bermanfaat dalam membuat keputusan strategi, strategi yang baik ketika mampu mengintegrasikan antara kekuatan dan peluang dan pada masa yang sama dapat meminimumkan kelemahan dan ancaman. Pemilihan dan penetapan strategik tidak bertentangan dengan Islam. Dan istilah strategi bukanlah perkara baru dalam Islam, karena konsep strategi telah diamalkan oleh Rasulullah s.a.w. Keputusan-keputusan strategi harus mempertimbangkan nilai-nilai ummah (stakeholder), kesejahteraan dan kemaslahatan ummah yang merupakan falsafah sosial sebuah organisasi. Oleh itu, perumusan strategi perlu dilandasi oleh syariah. Inti syariah adalah menjaga agama, menjaga jiwa, menjaga akal, menjaga keturunan dan menjaga harta benda. Pemilihan alternatif dan penetapan strategi adalah menjawab pertanyaan bagaimana (how) mencapai apa yang dikehendaki oleh organisasi yang telah ditetapkan sebagaimana digambarkan 
dalam pernyataan visi, misi dan tujuan. Tahapan keempat ini selaras dengan asas perencanaan strategik berparadigma kedelapan (AIPS.8).

Hasil yang diharapkan dari tahapan keempat ini adalah keputusan strategi yang diputuskan bersama stakeholder untuk mencapai visi, misi dan tujuan yang telah ditentukan pada tahapan sebelumnya. Oleh itu, untuk mendapat keputusan strategi yang baik, tim perencanaan perlu mengembangkan prinsip-prinsip Islam sebagai landasan dalam melakukan proses perencanaan strategik. Prinsip-prinsip tersebut antaranya adalah asas tauhid (AIPS.1), asas musyawarah (syuura) (AIPS.3), asas keadilan (adl') (AIPS.9), asas amanah (AIPS.14), asas bertanggungjawab (mas'uliyah) (AIPS.9), asas keseimbangan (tawazun) (AIPS.11), asas kadar prioriti (awlawiyat) (AIPS.12) dan asas kemaslahatan (mashlahah) (AIPS.6). Sedangkan, nilai-nilai yang perlu dikembangkan, harus bertunjangkan tauhid (keberhasilan atau kegagalan hanya karena izin Allah); kebebasan menyatakan fikiran dan kesediaan mendengar pendapat; bersikap dengan memperhitungkan pelbagai perkara sesuai pada tempatnya (tawazun); pengambilan keputusan harus diputuskan secara kolektif (jama'y); bertanggungjawab (mas'ulyah) terhadap apa yang diamanahkan; dan memikirkan kemaslahatan (mashlahah) bersama.

Tahapan 5 : Menyusun Rancangan Implementasi (when).

Tahapan terakhir proses perencanaan strategik adalah menyusun rancangan implementasi sebagai konklusi proses perencanaan strategik. Untuk mengimplementasikan keputusan strategi, diwujudkan dalam bentuk pembuatan program, penyusunan anggaran dan pembuatan prosedur yang dinyatakan dalam bentuk dokumen. Dalam dokumen menerangkan secara terperinci tentang program dan strategi yang telah diputuskan. Dokumen dari hasil perencanaan strategik merupakan garis panduan implementasi (mujahadah) sekaligus sebagai garis panduan pengawasan (muhasabah) pelaksanaan proyek. Dalam tahapan ini terdapat perkara penting yaitu tindakan membagi-bagikan sumber daya organisasi bagi melakukan setiap program dan setiap program hendaknya memperhitungkan skala prioriti. Tahapan ini bermaksud menggambarkan waktu (when) implementasi sebuah proyek dan sumber daya organisasi yang diperlukan dan tahapan ini sudah selaras dengan asas perencanaan strategik yang kesepuluh (AIPS.10).

Hasil yang diharapkan dari tahapan terakhir ini adalah satu set dokumen perencanaan strategik yang berfungsi sebagai garis panduan implementasi (mujahadah) dan pengawasan (muhasabah) sebuah proyek. Oleh sebab dalam tahapan terakhir ini terdapat 
tindakan kritikal, prinsip-prinsip Islam berikut dapat dijadikan landasan oleh tim perencanaan dalam melakukan proses perencanaan strategik, yaitu asas tauhid (AIPS.1), asas musyawarah (syuura) (AIPS.3), asas keadilan ( $a d l$ ') (AIPS.9), asas amanah (AIPS.14), asas bertanggungjawab (mas'uliyah) (AIPS.9), asas kemaslahatan (mashlahah) (AIPS.6), asas keseimbangan (tawazun) (AIPS.11), asas bertahap (tadarruj) (AIPS.13), asas prioriti (awlawiyat) (AIPS.12) dan asas bertawakal (AIPS.15). Sedangkan nilai-nilai yang perlu dikembangkan antaranya harus berprinsipkan tauhid (keberhasilan atau kegagalan hanya karena izin Allah); harus menghindari sifat pemubaziran sumber daya organisasi; bersikap dengan memperhitungkan pelbagai masalah sesuai pada tempatnya; segala keputusan perlu diputuskan secara kolektif (jama'y); harus dikembangkan rasa tanggungjawab (mas'uliyah); bersikap dan berjiwa berserah kepada Allah setelah melakukan ikhtiar (bertawakal); dan program harus bersifat fleksibel (muru'nah).

\section{KESIMPULAN}

Berdasarkan uraian di atas, dapat disimpulkan bahwa perencanaan strategik adalah bagian penting dan pertama dalam sistem manajemen. Ia adalah salah satu bagian ilmu pengetahuan yang dikembangkan dan digunakan oleh manusia, tidak terlepas umat Islam dalam memantapkan sistem manajemen sebuah organisasi. Konsep perencanaan strategik yang ada saat ini dan kononnya dirumuskan oleh Barat masih memisahkan nilai-nilai Islam yang sepatutnya holistik di dalam konsepnya. Ia lebih mengedepankan nilai-nilai material sebagai tujuan utamanya. Oleh itu, konsep perencanaan strategik konvensional ketika dijadikan pendekatan dalam melakukan proses perencanaan strategik sering kali berlaku kegagalan.

Perencanaan strategik berparadigma Islam merupakan sebuah jawaban dan pengembangan dari konsep perencanaan strategik yang ada yang dikemas dengan asas-asas Islam. Perencanaan strategik berparadigma Islam lebih komprehensif berbanding dengan perencanaan strategik konvensional. Sebab ia holistik dengan nilai-nilai dan prinsip-prinsip Islam sebagai landasan tim perencanaan dalam melakukan proses perencanaan strategik. Perencanaan strategik berparadigma Islam lebih mengedepankan nilai-nilai dan kesejahteraan stakeholder. 


\section{DAFTAR PUSTAKA}

Ahmad Ibrahim Abu Sinn. 2006. Manajemen syariah (sebuah kajian histories dan kontemporer). Terj. Dimyauddin Djuwaini.: PT Raja Grafindo Persada, Jakarta.

Ahmad, A.K. 2005. The six-'S' model: understanding the Islamic principles of management. Dlm. Mazilah Musa \& Shaikh Mohd Saifuddeen Shaikh Mohd Salleh. (Edited). Quality Standard From The Islamic Perspective, hlm. 43-62. Sungai Buloh: Al-Hikmah Sdn. Bhd.

Alawiyah, T. t.th. Membangun integrasi imtak dan iptek. http://www.geocities.com/ ibnumoeslih/imtakiptek.html [5 Mei 2007].

Allison, M. \& Kaye, J. 2005. Perencanaan Strategis Bagi Organisasi Nirlaba. (pedoman praktis \& buku kerja. Terj.: Yayasan Obor Indonesia. Jakarta

Al-Munawar, Said Agil Husin. 2004. Al-Qur'an mambangun tradisi kesalehan hakiki. Cet. ke-3.. Ciputat Press. Jakarta

Al-Qardhawy, Yusuf. 1996. Fikih prioritas (urutan amal yang terpenting dari yang penting). Terj. Moh. Nurhakim. Subhan (Peny.).: Gema Insani Press. Jakarta

Al-Qardhawy, Yusuf. 1999. Anatomi masyarakat Islam. Terj. Dr. Setiawan Budi Utomo.: Pustaka Al-Kautsar. Jakarta

Al-Qardhawy, Yusuf. 2003. Wawasan Islam antara keaslian dan kemodenan. Cet. ke-4. Terj. Hj. Ahmad Nuryadi Asmawi. Batu Caves Darul Ehsan: Thinker's Library Sdn. Bhd. Selangor

An-Nabhani, Taqiyuddin. 2006. Daulah Islam. Terj. Umar Faruq. Tim HTI (pnyt.).: Hizbut Tahrir Indonesia (HTI)-Press. Jakarta

Anon. 2005. Pengantar Epistemologi Dalam Pemikiran Islam. ISLAMIA. Thn. II No.5, April Juni 2005.

Antonio, M.S. 2007. Muhammad SAW the Super Leader Super Manager. Cet.Ke-3. Ed. Nuruddin Mhd. Ali, Cecep H.Sholehuddin.: Tazkia Multimedia \& ProLM Centre. Jakarta

Azman Che Omar. 2003. Manajemen di Malaysia dari perspektif Islam.: Dewan Bahasa dan Pustaka. Kuala Lumpur

Baiquni, A. 1983. Islam dan Ilmu Pengetahuan Modern.: Pustaka. Jakarta

Bakar, O. 1997. Hierarki ilmu (membangun rangka pikir islamisasi ilmu). : Mizan. Bandung

Bryson, M.J. 2004. Strategic planning for public and nonprofit organizations (A guide to strengthening and sustaining organization achievement). Ed. ke-3. San Francisco: John Wiley \& Sons. 
Bukhari Muslim. t.th. Hadits Shahih. Dikumpulkan oleh Hussein Bahresi.: Karya Utama. Surabaya

Danial Zainal Abidin. 2006. Tip-Tip Cemerlang dari Quran. cet. Ke Tujuh.: PTS Millennia Sdn Bhd. Kuala Lumpur

David, R.F. 2003. Perencanaan strategik (konsep dan kes). Terj.: Prentice Hall.

Departemen Agama. 1979. Al-Quran dan Terjemahannya. Malaysia

Dictionary of Business Terms 2007. http://www.allbusiness.com/glossaries/masterplan/4954351-1.html.

Djamil, F. 1997. Filsafat hukum Islam.: Logos Wacana Ilmu. Jakarta

Djunaedi, Achmad. 2000. Keragaman pilihan corak perencanaan untuk mendukung kebijakan otonomi daerah. Paper dibentangkan dalam Seminar \& Temu Alumni MPKD 2000, di Werdhapura, Sanur Bali, 27-30 Ogos 2000.

Ensiklopedia Oxford. 2001. Dunia Islam modern. Jil. ke 1-5. Editor John L. Esposito.: Mizan. Bandung

Fadillah Mansor. 2006. Kualiti kerja dalam organisasi: tinjauan dari perspektif manajemen Islam. Dlm. Ab. Mumin Ab. Ghani \& Fadilah Mansor (pnyt.). Dimensi manajemen Islam (mengurus kerja dan mengurus modal insan), hlm. 1-21. Kuala Lumpur: Universiti Malaya.

Gaspersz, V. 2004. Perencanaan strategik untuk peningkatan kinerja sektor publik.: PT Gramedia Pustaka Utama. Jakarta

Ghazali Haji Abdul Wahab. 2001. Masaleh mursalah sebagai sumber perundangan Islam. Dlm. Siti Zalikhah Haji Md. (pnyt.). Al-Syariah (konsep dan perundangan Islam), Jil. 1, hlm. 1-19.: Dewan Bahasa dan Pustaka. Kuala Lumpur

Hafidhuddin, D. \& Tanjung, H. 2003. Manajemen syari'ah (dalam praktik).: Gema Insani. Jakarta

Haim Hilman Abdullah. 2005. Manajemen strategic.: McGraw-Hill. Malaysia

Harussani Haji Zakaria. 2005. Nilai murni teras manajemen cemerlang. Kertas Kerjas. Seminar Manajemen Cemerlang II (kemahiran manajemen asas keutuhan organisasi. Anjuran Universiti Utara Malaysia., 29-31 Julai 2005. Kedah

Hunger, J.D. \& Wheelen, L.T. 2001. Manajemen strategis. Terj. Julianto Agung S.: Andi Offset. Yogyakarta

Ideris bin Endot. 2004. Perencanaan pembangunan Malaysia: kajian dasar dan strategi manajemen sumber ekonomi dari perspektif Islam di Negeri Terengganu, Darul Iman. Tesis Dr. Falsafah, Fakulti Pengajian Islam, Universiti Kebangsaan Malaysia. 
Ismail Nor. 2000. Kepimpinan Nabi Muhammad SAW (manajemen altrustik model ikutan sepanjang masa, perbandingan silang dengan kepimpinan dan manajemen semasa.: Utusan Publications \& Distributions Sdn. Bhd. Kuala Lumpur

Kamus Dewan. 2005. Ed. ke-4. Cet. ke-1.: Dewan Bahasa dan Pustaka. Kuala Lumpur

Khallaf, A.W. 1996. Kaidah-kaidah hukum Islam (ilmu usul figh). Cet. ke-6.: PT. Raja Grafindo Persada. Jakarta

Kurzman, C. 2001. Wacana Islam liberal. Terj. Bahrul Ulum \& Heri Junaidi. Peny. E.Kusnadiningrat \& Din Wahid.: Paramadina bekerjasama dengan Yayasan Adikarya (IKAPI) dan The Ford Foundation. Jakarta

Madjid, A., Mufid, Suyoto, Tobroni, Nurhakim, M., Rahman, F. 1989. Al-Islam. Malang: Pusat Dokumentasi dan Publikasi Universitas Muhammadiyah Malang.

Madjid, N. 2000. Islam doktrin dan peradaban: sebuah telaah kritis tentang masalah keimanan, kemanusiaan dan kemoderenan. Cet. ke-4.: Yayasan Wakaf PARAMADINA Jakarta.

McNamara, C. 2001. Strategic planning (in nonprofit of for-profit organizations). http://www.managementhelp.org/np_progs/sp_mod/str_plan.htm [28 Julai 2006].

Mohamed Yusof Nor, Nizam Abd. Latif \& Abdul Karim Ihwan. 1999. Manajemen strategic dari perspektif Islam. Dlm. Zainal Abidin Mohamed (pnyt.). Manajemen strategik di sektor pendidikan, hlm. 185-203. Serdang: Universiti Putra Malaysia.

Mohd. Affandi Hassan. 1990. Pendekatan tauhid dalam manajemen dan pentadbiran awam: konsep, prinsip, dan model alternative. Dlm. Shafie Hj Mohd. Salleh \& Mohd. Affandi Hassan. (pnyt.). Kecemerlangan pentadbiran dasar dan amalan dalam Islam, hlm. 26-71.: Institut Tadbiran Awam Negara (INTAN). Kuala Lumpur

Mohd. Nasir Omar. 2005. Gagasan Islamisasi ilmu.: Utusan Publications \& Distributors Sdn. Bhd. Kuala Lumpur

Mohd. Shahar bin Sidek. 1991. Manajemen organisasi dari perspektif Islam. Dlm. Mohd Shahwahid Haji Othman (pnyt.). Manajemen organisasi dari perspektif Islam, hlm. 1-32. Serdang: Persatuan Siswazah Islam Universiti Pertanian Malaysia (PERSIS).

Mohd. Sharifudin bin Khairudin. 2004. Analisis perencanaan strategik menurut perspektif Islam di sektor sosial, unit perencanaan ekonomi, suk negeri prak. Kertas Kerja. Pengajian Syariah Akademi Pengajian Islam Universiti Malaya.: Universiti Malaya. Kuala Lumpur

Muhaimin. 2006. Nuansa baru pendidikan Islam (mengurai benang kusut dunia pendidikan).: PT. Raja Grafindo Persada. Jakarta

Muliawan, U.J. 2005. Pendidikan Islam integrative (upaya mengintegrasikan kembali dikotomi dan pendidikan Islam).: Pustaka Pelajar. Yogyakarta 
Mustafa Daud. 2000. Manajemen Islam: falsafah, ciri dan profesionalisme. Dlm. Abdul Ghafar Don, Berhanundin Abdullah, Zulkiple Abd. Ghani. Dakwah dan manajemen Islam di Malaysia konsep dan pelaksanaan, hlm. 29-36.: Universiti Kebangsaan Malaysia. Bangi

Naceur Jabnoun. 1994. Islam and management.: Institut Kajian Dasar (IKD). Kuala Lumpur

Nik Mustapah Hj. Nik Hasan. 2007. Pendekatan keadilan sosial dalam membangun Negara. Dlm. Khairul Azhar Idris. (pnyt.). Keadilan Sosial dari Perspektif Islam, hlm. 1-14.: MPH Group Printing(M) Sdn. Bhd. Kuala Lumpur

Nik Mustapha bin Haji Nik Hasan. 2008. Quality and productivity: an Islamic perspective. Makalah Seminar MS1900:2005. Tarikh 30 Oktober 2008/1 Zulkaedah 1429H. Anjuran Institut Kefahaman Islam Malaysia (IKIM) dan SIRIM QAS International Sdn. Bhd.

Nurhakim Moh. 2000. Islam doktrin pemikiran dan realitas historis. Ed. Revisi.: Universitas Muhammadiyah Malang (UMM) Press. Malang

Othman Hj. Talib. 2000. Manajemen dakwah zaman Rasulullah SAW. Dlm. Abdul Ghafar Don, Berhanundin Abdullah, Zulkiple Abd. Ghani. Dakwah dan manajemen Islam di Malaysia konsep dan pelaksanaan, hlm. 17-28.: Universiti Kebangsaan Malaysia. Bangi

Purnomo, H.S. \& Zulkieflimansyah. 2005. Manajemen strategi.: Fakultas Ekonomi Universitas Indonesia. Jakarta

Rahardjo, M.D. 1990. Etika ekonomi dan manajemen.: Tiara Wacana. Jojakarta

Rais, M.A. 1999. Cakrawala Islam (antara cita dan fakta). Cet. ke-10.: Mizan. Bandung

Raja Malik Mohamed. 2003. Practical approach to ICT strategic planning.: Institut Tadbiran Awam Negara (INTAN). Kuala Lumpur

Rowley, J.D.\& Sherman, H. 2002. Implementing the strategic plan. Journal Planning for Higher Education. Summer: 5-14.

Sharifah Hayaati Syed Ismail. 2001. Perencanaan strategic dalam pentadbiran Islam: suatu tinjauan perbandingan. Jurnal Syariah. 9(1): 47-56.

Syedh Othman al-Habshi. 1989. Islam, ekonomi dan manajemen.: Perpustakaan Hizbi. Kuala Lumpur

Tahia Al-Ismail. 2002. Sejarah Nabi Muhammad SAW. Terj. Siti Sujinah Sarnap.: Perniagaan Jahabersa. Johor Bahru

Tripomo, T. \& Udan. 2005. Manajemen strategi. : Rekayasa Sains. Bandung 
Wan Liz Ozman Wan Omar. 1996. Manajemen Islam abad ke-21 (revolusi manajemen untuk keunggulan sektor awam dan korporat).: Utusan Publications \& Distributors Sdn.Bhd. Kuala Lumpur

Wan Mohd. Nor Wan Daud. 2003. Filsafat dan praktik pendidikan Islam Syed M. Naquib al-Attas. Terj. Hamid Fahmy, M. Arifin Ismail \& Iskandar Amel.: Mizan. Bandung

Wan Mohd. Nor Wan Daud. 2005. Epistemologi Islam dan tantangan pemikiran umat. Dlm. Majalah Pemikiran dan Peradaban Islam. Epistemologi Islam $\mathcal{E}$ Problem Pemikiran Muslim Kontemporer, hlm. 51-74. “ISLAMIA” Thn. II No.5, April - Juni 2005.

Widjajakusuma, M.K. \& Yusanto, M.I. 2002. Pengantar manajemen syari'ah.: Khairul Bayan. Jakarta

Yahya, M. \& Rahman, F. 1993. Dasar-dasar pembinaan hukum (figh-Islam). Cet. ke-3.: AlMa'arif. Bandung

YAPEIM. 2005. Manajemen dalam Islam (menghayati prinsip dan nilai Qurani).: Akademi Manajemen YPEIM Sdn.Bhd. Kuala Lumpur

Yazid, A. 2004. Islam akomodatif (rekontruksi pemahaman Islam sebagai agama universal).: Lembaga Kajian Islam (LkiS). Yogyakarta

Yeoh, M. 1993. Management strategies for vision 2020 (developing competitive strategies for the winnig edge.: Pelanduk Publications. Petaling Jaya

Yusof Ismail. 1991. Mengurus secara Islam.: A.S. Noordeen. Kuala Lumpur

Zainal Abidin Mohamed. 1998. Manajemen strategik.: Utusan Publications \& Distributor Sdn Bhd. Kuala Lumpur

Zainal Abidin Mohamed. 1999. Perencanaan strategik dan industri pendidikan. Dlm. Zainal Abidin Mohamed (pnyt.). Manajemen strategik di sektor pendidikan, hlm. 1-30. Serdang: Universiti Putra Malaysia.

Zawiyah Mohammad Yusof \& Masnizah, Mohd. 2005. Sains Social \& Teknologi Maklumat. Ed.Kedua.: Pearson Prentice Hall. Malaysia. 